\title{
Check for \\ updates \\ An Empirical Study on Role of Art to Raising City Image from the Context of Youth Perceptions: Semarang City, Indonesia
}

\author{
Effendy Sigit ${ }^{1}$, Nadira Elkalam² ${ }^{2}$ Jue Ma1', Isami Kinoshita1 \\ ${ }^{1}$ Environmental Science and Landscape Architecture Course, \\ Graduate School of Horticulture, Chiba University, Japan \\ 2Urban and Regional Planning, Undergraduate School of Engineering Faculty, \\ Diponegoro University, Indonesia \\ ahfa4343@chiba-u.jp*, Nadira.elkalam19@pwk.undip.ac.id, \\ axma0792@chiba-u.jp, isamikinoshita@faculty.chiba-u.jp
}

\begin{abstract}
In recent years, cities are heavily investing in visual identity and its image. Literature revealed art has been used as a tool to escalate the city image by improving visual quality. This paper present of identifying the role of art in raising city image in the context of youth perception. The paper engages a case study in Kampung Pelangi, Semarang city. Likewise to response to the rapid change of urban city, Semarang city was attempted to paint the slum area becomes more colorful and attractive. Thus, potentially brought an impact to the overall visual quality in the city. The online questionnaire was used and collected 78 respondens. The study employs a combination of statistics and descriptive analysis. The variety of statistical analysis performed to examined the significant correlation. The multiple linear regression analysis showed the significant variable on a longer period of stay whereas lack of evidence for other related variables. Moreover, the correlation analysis was used to examined the hypothesis in chi-square test. The result obtained significant correlation was showed art element in Kampung Pelangi potential to escalate image in a district scale although lack of evidence to indicate that art in Kampung Pelangi could contributes to raising the image of Semarang city. Additionally, the study allows to generated conceptual matrix on the relationship of public art (publicity) and city image (imageability) towards spatial sustainability. The study is limit in one type of sample, and a small number of respondent might affect the result.
\end{abstract}

Keywords: Public art; city image; youth perception; imageability

eISSN 2398-4295 @ 2019. The Authors. Published for AMER ABRA cE-Bs by e-International Publishing House, Ltd., UK. This is an open-access article under the CC BY-NC-ND license (http://creativecommons.org/licenses/bync-nd/4.0/). Peer-review under responsibility of AMER (Association of Malaysian Environment-Behaviour Researchers), ABRA (Association of Behavioural Researchers on Asians) and cE-Bs (Centre for EnvironmentBehaviour Studies), Faculty of Architecture, Planning \& Surveying, Universiti Teknologi MARA, Malaysia.

DOI: http://dx.doi.org/10.21834/ajbes.v4i16.174 


\subsection{Introduction}

Various studies have been done to clarify the roles of art in the city. Scholars have emphasizing roles of art for social, economic, beautification (S. S. Omar, Sakip, \& Akhir, 2016) and politics (Obed Bima Wicandra, 2005) impacts. However, entering the age which demands made the city need to perform well by giving visual identity. The presence of public art in the city can contribute to improving the excitement of city spaces and make the city more pleasant places; also it contributes to improving the city life and its image (Motoyama \& Hanyu, 2014). Studies give evidence that aesthetic environments improve wellbeing, behavior, cognitive function and mood (Rautio, Filatova, Lehtiniemi, \& Miettunen, 2018). Omar et al., (2016) discussed that art helped the process of urban regeneration. Art aimed at activating urban space firstly and gradually became a way to express current issues and to communicate with its exposition places (Rendell, 2006). Also, the emergence of the Pompidou Centre can prove that artworks play the roles in creating the place identity (Januchta-Szostak, 2010).

In recent years, many cities are heavily investing in cultural industries and cultural image (Vanolo, 2008). Each city has a unique identity, which composed images and memories either negative and positive (Riza, Doratli, \& Fasli, 2012). Literature reveals to create a sustainable identity, and the city element needs to consider contextual of harmony (Riza et al., 2012). Moreover, city authorities are often used 'quick fix' as solutions to raising city image problems (Quinn, 2005). Thus, able to expressed and give a distinguishing element in a temporary period. Also, bring a tourist impression to the city, means attractive newness and mystery (Mansour, 2011).

Physically, art helps to transform the dull and the decaying city simultaneously to creating more opportunity for local and tourists to socialize (S. S. Omar et al., 2016). Unlike the other city elements, art often used as a complementary element for the other object such as architecture, park or even related to city festival. Nevertheless, it makes art becomes the focal point. Besides, art in the city plays an vital role by giving the dominant visual in the surrounding landscape (Effendy, 2018). The visual quality produced on imageability which evokes a sharp image to the observer (Lynch, 1960b). Rendell, (2006) thought the art could also provide certain kinds of tools for self-reflection, critical thinking and social change which allow the observer to create their image.

City image was generated by a long association between the observer and his environment. The city image composed of the view of urban elements such as monumental buildings, public spaces and other special features (Riza et al., 2012) . (Lynch, 1960a) Classify into five elements that can structure the city image which is districts, nodes, edges, paths, landmarks. Those elements are often overlapping each other, district structure by nodes, nodes define by the edge, edge penetrates by path, and path sprinkles by landmark. Those five physical elements need to have imageability capabilities.

Likewise, to respond to the rapid change of urban city, Semarang city was attempted to raising the image of its city by painting the slum area Kampung Pelangi. The colorful painting in the village was succeeded to attract young people and bring a new image of the place. The attractive environments can enhance the user's experience (Daykin, Byrne, Soteriou, \& O'Connor, 2008). However, the existence of art in Kampung Pelangi potentially affected the 
observer perception towards the whole image of the city. Hence, the study comes with the question whether the theme of colorful in Kampung Pelangi feels does not match for the overall image of Semarang city. The study performed to respond to the issue and to identify from the perspective of youth towards the contemporary movement and spatial sustainability.

\subsection{Aim and Objectives}

This paper aimed at identifying the role of art in Kampung Pelangi to raising city image from the context of youth perceptions. In simultaneous, the objectives are to investigate various variable in the contribution of giving perceptions towards art for city image. Moreover, to examine the null hypothesis on the significant correlation of art elements onto raising image in district scale also a city. Furthermore, the study performed to generates a conceptual matrix on the relationship public art (publicity) and city image (imageability) towards spatial sustainability.

\subsection{Limit of study}

The study is limit on one sample of respondents. University students have been chosen as a representative group of youth. However, a small number of respondents might effected the results.

\subsection{Literature Review}

\subsection{Publicity and imageability}

This study took on an exploratory relationship of public art in terms of publicity and city image in terms of imageability towards spatial sustainability. Spatial sustainability referred to identify and preserve a vital element has potentially become a high imageability (Kinoshita, I., Binder, H., \& Okabe, A., 2012). Applayerd (1969) elaborate production of an image on single building need to emphasize on size and shape and its inattention to the location and behavior of users, also visibility, contour, and social significance. Brookfield et al., (2013) emphasize accessibility as an indicator to determine the quality of public space, approachability, distance and the ability to be entered.

The literature revealed that there is a gap between public art with the public's perception (Hall \& Robertson, 2001). In general, public perceptions were more public impression which is a lack of public contribution for overall city images (Mansour, 2011). Zebracki (2013) on his study conveys that public perceptions were further situated in public cognitive, spatial, aesthetic, social, and symbolic to public art and its site. ZEBRACKI \& Palmer ( 2018 ), indicate an artwork with engaged by the public might become embraced as a positive city image. However, "publicness quality" need to be considered instead just attractiveness of public art and its site. Some scholars elaborate on the publicity ability bound with the environment's imageable features. McCunn \& Gifford (2017) sump up visibility regards to the ability for mental mapping accessibility regards to the location. Environmental quality can be partially determined imageability, so that is mapped one's mind relates to and uses that place to positive ways (McCunn \& Gifford, 2017). 
The visual image of a city was portrayed by the observer in a multi dimention views. It provides a memorable experience for tourist and pride for the resident (Gilboa, Jaffe, Vianelli, Pastore, \& Herstein, 2015). Lynch (1960b) identify the image of a place consist of three fundamental factors; namely identity, structure, and meaning. Identity defines as workable image requires as identification objects which imply on its distinction from the othe objects. Meaning define as non physical characteristics which may enhance the imageability of an element. The structure is seen as a framework of social relation. Thus attributes need a function of legibility. The ability of the city to deliver an image to the city dweller can be measured from its legibility. Legibility is crucial in the city setting, to analyze some detail and try to show the concept of a city might be used to rebuilding the city (Lynch, 1960b). The study compiles the attributes in Table 1.

Table 1: Attributes publicity and imageability

\begin{tabular}{|c|c|c|c|}
\hline \multicolumn{4}{|c|}{ Attributes } \\
\hline \multicolumn{2}{|c|}{ Public Art (Publicity) } & \multicolumn{2}{|c|}{ City Image (Imageability) } \\
\hline $\begin{array}{l}\text { Parameters to evaluate } \\
\text { (Applayerd, 1969), } \\
\text { (Brookfield et al., 2013) }\end{array}$ & Indicators & $\begin{array}{l}\text { Parameters to evaluate } \\
\text { (Lynch, 1960b) }\end{array}$ & $\begin{array}{l}\text { Indicators } \\
\text { (Casanovas, 2005) }\end{array}$ \\
\hline \multirow[t]{2}{*}{ Visibility } & Contrasts & Identity & Distinctiveness \\
\hline & Dominants & & Entity \\
\hline \multirow[t]{4}{*}{ Accessibility } & Distance & & Wholeness \\
\hline & Approachability & & $\begin{array}{l}\text { Independence from } \\
\text { the context }\end{array}$ \\
\hline & & Structure & Color \\
\hline & & & Shape \\
\hline \multirow[t]{7}{*}{ Public participation } & Recognition & & Form \\
\hline & Decision & & Materials \\
\hline & & Meaning & Functional \\
\hline & & & Recognizability \\
\hline & & & Modifiability \\
\hline & & & Usefulness \\
\hline & & & Fitness to the context \\
\hline
\end{tabular}

(Source: Author)

\subsection{The portrayal city image by youth}

The fundamental concept of city image was perceived from the relationship between the observer and his environment, and it generated onto the public's perceptions. However, this study follows public proximities regarding educational background and familiarity also experience. Therefore, this study examined the response of youths towards their knowledge in the context of art for city image. Suthasupa (2012) elaborates the ability of youth to explain their abstract thinking towards city image to other people. The existance of the youth in 
community have few sources of the positive public image of their neighborhood (Dukes et al., 2016). However, studied argued level of youth participation in the neighborhood scale is still low and ineffective (D. Omar, Omar, Othman, \& Yusoff, 2016). Moreover, the roles of art could engage youths to improve their environment to participate in urban planning (Tsevreni, 2014). Also, pleasing aesthetics give a youth a positive experience and connection with his environment (Bishop, 2012). Although, young people are easy to lose their interest very quickly, unless it moves, changes, engages or even better and interact with them (Gschwend, 2015).

Adolescents are in the group of age likely to interpret the environment similarly, due to common and temporal experience (Suthasupa, 2012). The age of youth will vary by culture, by country, and by function and may range 13 to 35 (Suthasupa, 2012). University students within the average age are 21 years old is used as a representative of youth in this study. The proximities level measured on the respondents' criteria such as background study, age, length of stay, domicile is used to the response of familiarity towards art in Kampung Pelangi.

\subsection{Methodology}

This study engages a case study as an approach. Moreover, the respondent's perceptions were obtained as the primary data to discuss. Qualitative and quantitative data were used to balance the argument. The results were expected to examine the significance of invariance to explore the general objectives. Furthermmore, the result allow to generate conceptual matrix to evaluate the proximity on relations of publicity and imageability in terms of art for raising city image.

\subsection{Case Study Area}

The study area is located in Kampung Pelangi, Semarang city (figure 1). Due to the fastchanging shift from local to globalization, Semarang city also attempts to invest a positive image by painting the slum settlement located in the central of the city. The new visual indicated positive impacts on city branding, primarly through the internet. Many online media have brought up the issue as a successful case. The slum village was "transformed" into a colorful village that became a new popular attraction for local tourism. However, the existence of new visual in Kampung Pelangi has brought a distinction for overall Semarang city image.

Semarang city as the capital city of central Java was developed and well known as a historical city. The previous study revealed the remaining historical buildings and its landscape was perceived Semarang as a historical image. This study was inventory and identify the recognizable of remaining buildings and landscape as category elements to build a city image by Lynch theory (Table 2). Therefore, the study considered to giving a unique insight to using art for raising city image. 
Sigit, E., et.al. / Asian Journal of Behavioural Studies (AjBeS), 4(16) May / Aug 2019 (pp.1-17)

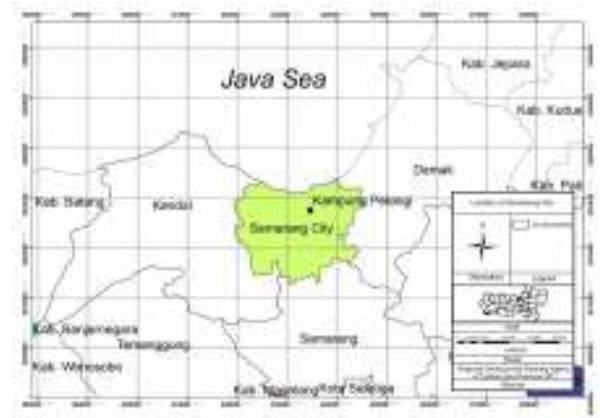

(a)

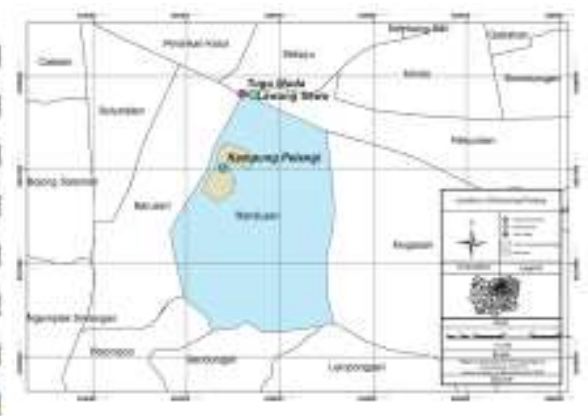

(b)

Figure 1: Study location (a) Semarang city (b) Kampung Pelangi (Source: Author)

Table 2: Identify recognizeable elements

\begin{tabular}{|c|c|c|}
\hline $\begin{array}{l}\text { Recognizeable } \\
\text { elements (Lynch, } \\
\text { 1960b) }\end{array}$ & Name & Image and Location \\
\hline Landmark & $\begin{array}{l}\text { Tugu muda and } \\
\text { Lawang Sewu }\end{array}$ & Simpang Tugu muda, Sekayu \\
\hline 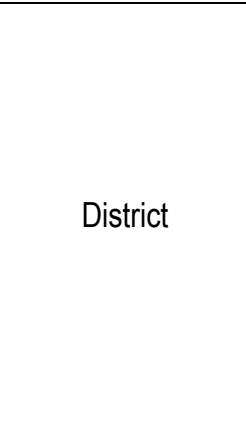 & $\begin{array}{l}\text { Kampung } \\
\text { Pelangi }\end{array}$ & Randu Sari \\
\hline
\end{tabular}


Sigit, E., et.al. / Asian Journal of Behavioural Studies (AjBeS), 4(16) May / Aug 2019 (pp.1-17)

\begin{tabular}{|c|c|c|}
\hline & Kota Lama & $\frac{9}{9}$ \\
\hline \multirow{3}{*}{ Path } & Pemuda street & 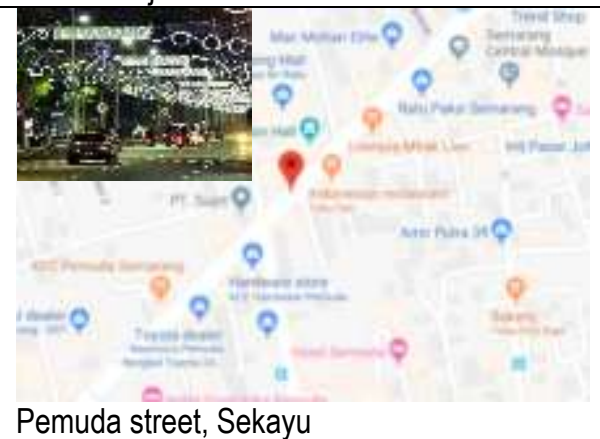 \\
\hline & Pahlawan street & 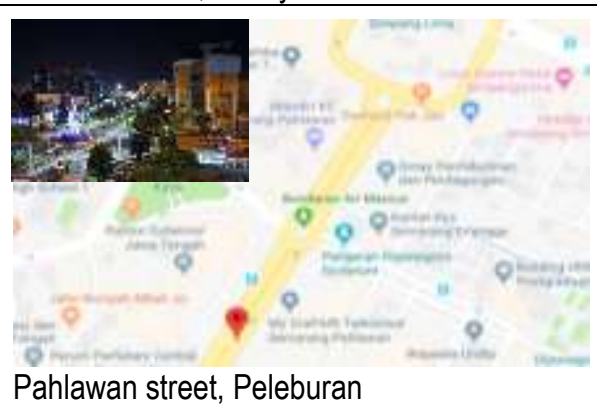 \\
\hline & $\begin{array}{l}\text { Pandanaran } \\
\text { street }\end{array}$ & = \\
\hline
\end{tabular}


Sigit, E., et.al. / Asian Journal of Behavioural Studies (AjBeS), 4(16) May / Aug 2019 (pp.1-17)

\begin{tabular}{|c|c|c|}
\hline \multirow[t]{2}{*}{ Nodes } & Simpang Lima & 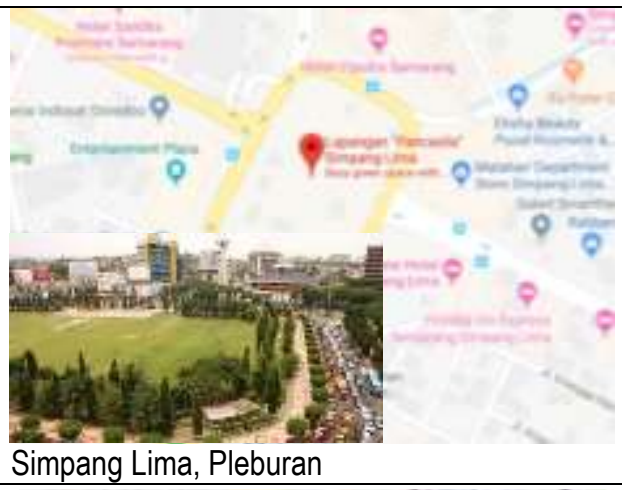 \\
\hline & $\begin{array}{l}\text { Simpang Tugu } \\
\text { Muda }\end{array}$ & $\begin{array}{l}\text { Simpang Tugu Muda, Sekayu } \\
\text { Sime }\end{array}$ \\
\hline Edge & $\begin{array}{l}\text { Mangkang Bus } \\
\text { Station }\end{array}$ & $\begin{array}{l}\frac{2}{9}+\frac{7}{9} \\
\frac{9}{9}\end{array}$ \\
\hline
\end{tabular}




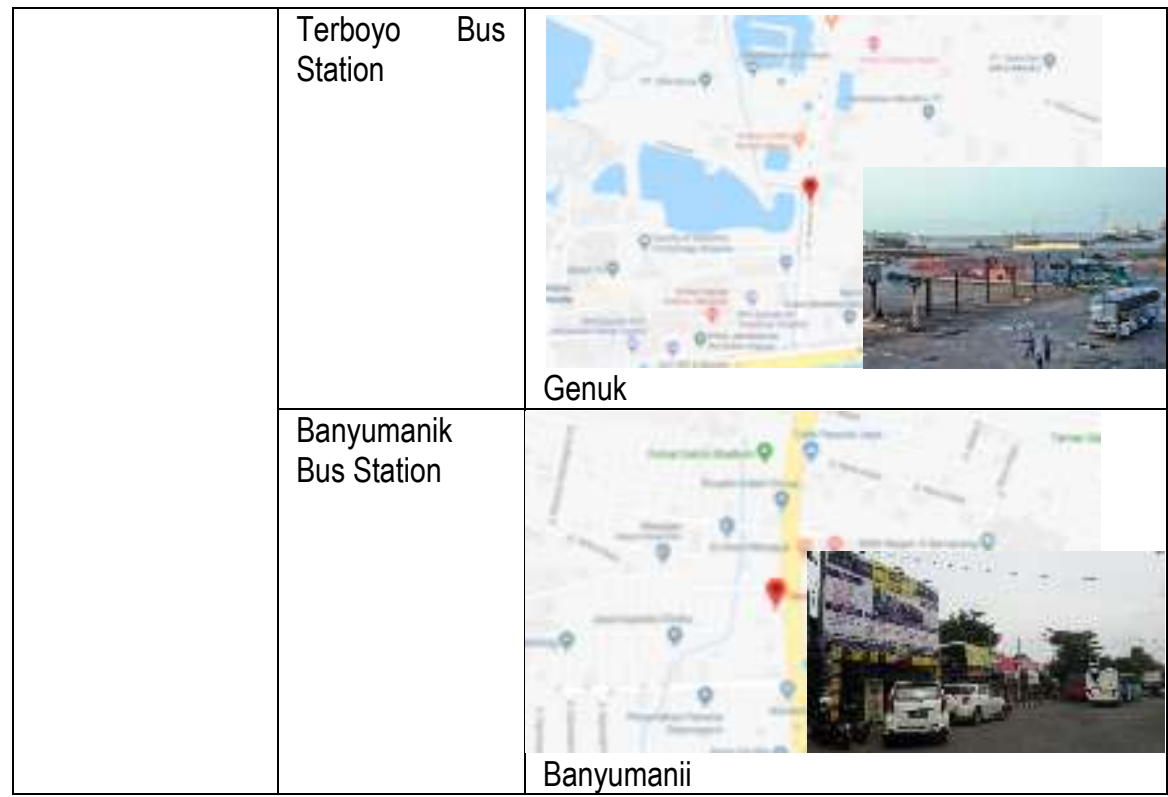

(Source: Modified by author (Images: google picture, Map: google map))

\subsection{Data collection}

The questionnaires distributed by using google form online surveys. The question consists of the general question to obtain the respondent's attributes (age, background study, domicile, a period of stay in Semarang city). Also, emphasizing on the familiarity towards the art in Kampung Pelangi to explore the respondent perception. Thus, consist a combination of multiple choice questions and open questions. The results were able to acquire the objectives answer and delineate the respondent's image in descriptive. This study employed a purposive sampling technique to reach a specific group of a sample. The study investigated a group of university student as a representative of the youth. The purposive sampling is done by distributing the link of the questionnaire online to a group of students. The specific keyword "university student in Semarang city" was used to control the population perception. The survey was completed in 14 days and collected a total of 78 respondents.

\subsection{Data analysis procedure}

The analysis data employs a combination of statistical analysis and descriptive analysis. Variety statistical analyses were done to reveal the relationship between variables. Multiple linear regression analysis was done to test the respondent's attributes variables to the influence on general perception towards roles of art to raising imageability. Correlation analysis Chi-squared test intended to reveal the significant correlation of variable art to give an impact to another city landmark later examined the significant impact to escalating new city image. Moreover, descriptive analysis was performed to discuss the respondents 
regarding existing of art in Kampung Pelangi. Finally, the study generates conceptual matrix on public art (publicness) and city image (imageability).

\subsection{Results}

\subsection{Attributes of respondents}

The online survey collected 78 respondents with the attributes (table 3 ) consist of $21 \%$ male and $79 \%$ female with an average level between the variable is $M=0.025$ (SD $=0.405$ ). Respondents age were in between $18-24$ years old whereas dominate age is 21 years old $(41 \%)$, the average age is $20.43(S D=1.035)$. Mainly respondents have had living in Semarang city is $2-3$ years $(44 \%)$ with the average is $M=3.5$ years $(S D=1.470)$. Meanwhile, respondents were domicile from outside of Semarang city $90 \%(M=3.384, S D=1.470)$. Generally, respondents were studying spatial study related $(79 \%)$ whereas others were studying social study $(21 \%)$ average level is $M=0.749(S D=0.406)$.

Table 3: Attributes of respondents

\begin{tabular}{lllllll}
\hline Attributes & N & $\%$ & Max & Min & Mean (M) & $\begin{array}{l}\text { standard } \\
\text { deviation } \\
\text { (SD) }\end{array}$ \\
\hline Gender & 78 & 100 & 1 & 0 & 0.025 & 0.405 \\
Male & 16 & 21 & & & & \\
Female & 62 & 79 & & & & \\
Age & 78 & 100 & 24 & 18 & 20.43 & 1.305 \\
$\begin{array}{l}18 \text { years old } \\
\text { 19 years old }\end{array}$ & 6 & 8 & & & & \\
20 years old & 15 & 19 & & & & \\
21 years old & 32 & 41 & & & & \\
22 years old & 8 & 10 & & & & \\
23 years old & 3 & 4 & & & & \\
24 years old & 1 & 1 & & & & \\
$\begin{array}{l}\text { Background } \\
\text { study }\end{array}$ & 78 & 100 & 1 & 0 & 0.749 & 0.406 \\
$\begin{array}{l}\text { Spatial study } \\
\text { (Urban }\end{array}$ & 62 & 79 & & & & \\
Social Study & 16 & 21 & & & & \\
Domicile & 78 & 100 & 1 & 0 & 0.128 & \\
\hline
\end{tabular}




\begin{tabular}{|c|c|c|c|c|c|c|}
\hline Semarang city & 8 & 10 & & & & \\
\hline Others & 70 & 90 & & & & \\
\hline Period of stay & 78 & 100 & 6 & 1 & 3.384 & 1.470 \\
\hline$<1$ year & 7 & 9 & & & & \\
\hline $1-2$ years & 11 & 14 & & & & \\
\hline $2-3$ years & 34 & 44 & & & & \\
\hline $3-4$ years & 6 & 8 & & & & \\
\hline $4-5$ years & 7 & 9 & & & & \\
\hline$>5$ years & 13 & 17 & & & & \\
\hline
\end{tabular}

(Source: Author)

\subsection{Effect of variables on general perceptions roles of art for city image}

Analysis using multiple linear regression was conducted to identify that variables significant effect on perception roles of art for city image (table 4). In this analysis, gender, the period of stay, background study and domicile were examined.

According to the regression analysis (table 4) showed that there was no significant difference in the effect of gender to perceived the art for city image ( $F=1.764, d f=3, p>0.05)$. Moreover, the results identify that respondents who have a background in the spatial study do not give a significantly different $(F=0.09, d f=3, p>0.05)$. The significant different showed in the period of stay in Semarang city $(F=0.140, d f=3, p<0.05)$, whereas most of the respondents were domicile from outside of Semarang city which identify there is was not significant effect $(F=0.098, d f=3, p>0.05)$.

Table 4: Multiple regression analysis

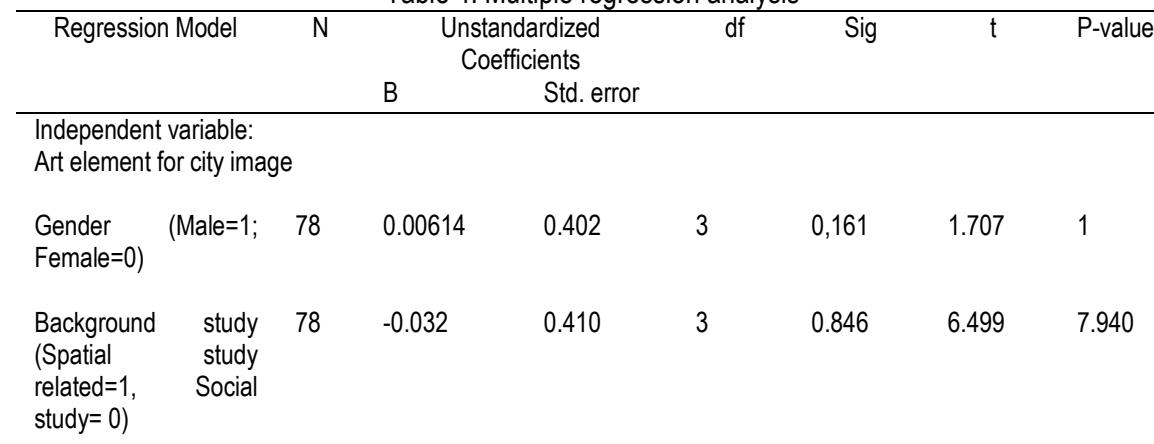




$\begin{array}{llllll}\text { Period of Stay } & 78 & -0.036 & 0.162 & 3 & 0,000^{*}\end{array}$

$\begin{array}{llllllll}\text { Domicilie (Semarang } & 78 & -0.037 & 0.340 & 3 & 0,960 & 0.978 & 0.330\end{array}$ city $=1$, Outside of semarang city $=0$ )

${ }^{\star}$ Significant level 0,05

(Source: Author)

\subsection{Variables effect on correlation analysis}

Chi-square test performed to identify the significant correlation between the attributes. The analysis allowed to examine the effects on roles of art to escalate image in district scale (table 5) and roles of art for whole city image (table 6).

The chi-square analysis (table 5) was able to test the null hypothesis $(\mathrm{HO})$ there is a significant correlation on that art in Kampung Pelangi has the potential to escalate the image of the city in district scale. Whereas, $(\mathrm{H} 1)$ there is no significant correlation art in Kampung Pelangi to escalate the city image in the district scale. According to the result analysis (table 5 ) showed that the null hypothesis was accepted ( $t$ table $=9.488$, Chi square $=7.858, P<0.05$ ). There was an association correlation between art element escalated the city image in the district scale.

Additionally, chi-square analysis was tested on roles of art for city image (table 6). The tested was performed to identify the null hypothesis $(\mathrm{H} 0)$ significant correlation art in Kampung Pelangi escalated the overall city image. Whereas $(\mathrm{H} 1)$ there is no significant correlation art in Kampung Pelangi to escalated whole city image. The results showed (table 6) that null hypothesis was not accepted, there was no significant correlation art in Kampung Pelangi to escalated city image ( $\mathrm{t}$ table $=9.488$, Chi square $=41.173, \mathrm{P}>0.05$ ).

Table 5: Chi-square analysis influence of art for the image in the district scale

\begin{tabular}{|c|c|c|c|c|c|}
\hline \multirow[t]{3}{*}{ Attributes } & $\mathrm{N}$ & df & \multicolumn{3}{|c|}{ Test } \\
\hline & & & Chi-Square & Value & $\begin{array}{l}\text { Chi- } \\
\text { Square } \\
\text { Table }\end{array}$ \\
\hline & 78 & 4 & & & \\
\hline Pearson & & & 7.858 & 0.0097 & 9.488 \\
\hline \multicolumn{6}{|c|}{ (Source: Author) } \\
\hline \multicolumn{6}{|c|}{ Table 6: Chi-square analysis art for city image } \\
\hline Attributes & $\mathrm{N}$ & $\mathrm{df}$ & & Test & \\
\hline
\end{tabular}




$\begin{array}{cc}\text { Value } & \text { Probability } \\ & \text { Square } \\ & \text { Table }\end{array}$

${ }^{*}$ Alpha level 0.05

(Source: Author)

\subsection{Publicity in public art for raising the imageability for city image}

The study allowed to generates a cumulative effect on the role of art for city image. The matrix below (Figure 2) explains the relationship between the two attributes, public art in terms of "publicity" and city image in terms of "imageability." Referred to Applayerd (1969) to amplify the production of image demanding by their imageability, visibility, roles and its significant ( including name and meaning). From the point of view sense of belonging, the meaning of publicity is close to "place identity" including visual space. However, Lefebvre (1991) argued that space does not exist in its right, but it created by society. Space representation is one of the cognitive experiment, which contains "art" and "playfulness."

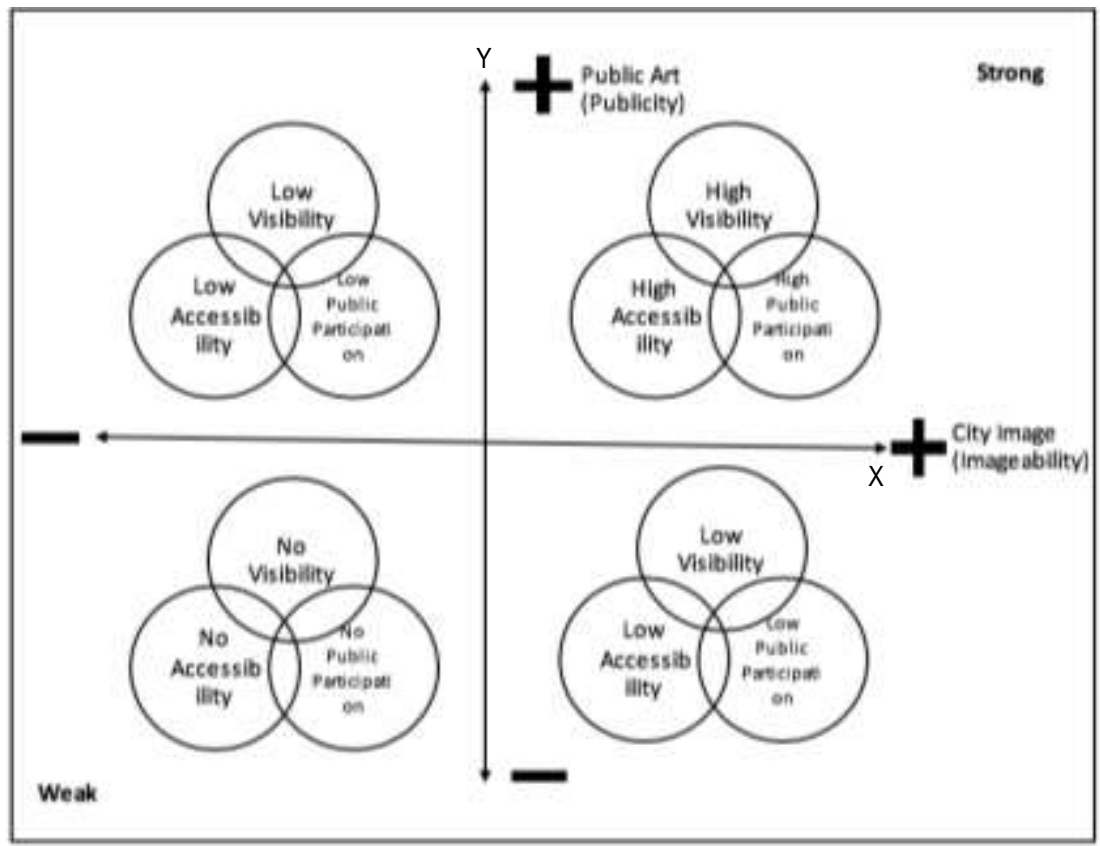

Figure 2: Matrix graphic "publicity" and "imageability"

(Source: Author) 
The matrix graphic (Figure 2) used to identify the intensity role of art for raising the image of the city. The matrix allowed to evaluate the proximity of the two attributes "publicity" and "imageability." However, those assessed attributes in the level of visibility, accessibility and public participation. Furthermore, each level designated in each column to state the level of intensity. Upright side shows the most substantial level, and the down left side shows the weak level.

The matrix attributes illustrated on the vertical and horizontal axis (Figure 2). Vertical axis (Y) named as public art attributes in terms of publicity and horizontal axis $(\mathrm{X})$ named as city image in terms of imageability. However, the relationship showed a positive and robust value if those attributes fulfilled the requirement variables which are high visibility, high accessibility, and high public participation. Otherwise, it showed the negative and weak value if those attributes have no visibility, no accessible and no public participation. However, the variable possibly has low value; in this case, need more evaluation for both attributes (vertical and horizontal axis).

\subsection{Discussion}

The study sought to identify roles of art in Kampung Pelangi to raising the image of Semarang city. The multiple regression analysis (table 4) showed that the period of stay was significantly different from portraying art in Kampung Pelangi to raising the image of Semarang city, whereas the variables gender, background of the study, and domicile were not significantly different from portraying art element in Kampung Pelangi to raising the image of Semarang city. The evidence associated with previous studied stated that young people tend to have a temporary feeling to accept the new things. However, abstract thinking leads to an exploration of their ability to perceive the urban environment and their relationship with the city image. Thus, interpreted that background attributes for young people do not significantly influence to portray city image.

The study provides further evidence on the significant correlation of the role of art in raising image in Kampung Pelangi. Thus, associated with the response which respondents were argued the impacts of art in Kampung Pelangi had eliminated the slum impression also changing the features. Also, the striking colors were brought the uniqueness and visual integration between the houses. Therefore, most respondents felt the significant impact of art in Kampung Pelangi in a positive way. Moreover, the further result showed there was no significant correlation roles art in Kampung Pelangi to raising Image of Semarang city. Respondents describe there was a lack of harmony and specific characteristics of Kampung Pelangi. Therefore, the results suggested to bringing unity and decent visual planning to using art for raising Image of the Semarang city.

By understanding the results above, this study allows generating a conceptual matrix to evaluate the relationship of art to raising city image. It showed as an axis named as publicity and imageability. Moreover, the matrix emphasizes three significant variables; visibility, accessibility, and public participation. However, to achieve an ideal condition, those variables need to be deeply evaluated. Learning from the case study, Kampung Pelangi showed that there still lack public participation whereas the existence of art only for a temporary period. 


\subsection{Conclusions}

This study identified the role of art in Kampung Pelangi to raising the image of Semarang city. The study was done by examined the perception of youth; this case a group of university students has been chosen as a representative. The results identified that the attributes for youth do not significantly influence for them to portray the influence of art for city image. However, the study showed the uniqueness of youth to perceive their thinking regarding their environment. Besides, the investigation revealed that youth potentially brought their critical thinking to perceive their ability to portray the city image. It showed on the significant influence of art to raising image in a district scale but still lack evidence to show that art in Kampung Pelangi could raise image for Semarang city.

Furthermore, the study produces the conceptual matrix to evaluate the proximity on relationship of art to raising city image. Attributes accessibility, visibility, and public participation need to assess to achieve the ideal condition towards spatial sustainability genuinely. However, the study suggested that a conceptual matrix need to improve for further study.

\section{Acknowledgement}

This study is part of doctoral study at Chiba University and supported by the Ministry of Education, Culture, Science and Technology (MEXT) scholarship.

\section{References}

Applayerd, D. (1969). A Predictive Tool for Architects and. Environment and Behavior, 1(2), 31-156.

Bishop, K. (2012). The Role of Art in a Paediatric Healthcare Environment from Children's and Young People's Perspectives. Procedia - Social and Behavioral Sciences, 38(December 2010), 81-88.

https://doi.org/10.1016/j.sbspro.2012.03.327

Brookfield, P., Coast, G., Council, C., Yasuda, K., Zebracki, M., Nasution, A. D., ... Maleki, S. N. (2013). Living as Form: Socially Engaged Art from 1991-2011. Procedia - Social and Behavioral Sciences, 201(2), 308-316.

https://doi.org/10.1007/s10708-011-9440-8

Casanovas, M. (2005). Public Art and Its Integration in the Urban Environment. Urban Regenaration: A Challenge for Public Art. https://doi.org/10.1016/0029-554X(81)90440-7

Daykin, N., Byrne, E., Soteriou, T., \& O'Connor, S. (2008). The impact of art, design and environment in mental healthcare: A systematic review of the literature. Journal of The Royal Society for the Promotion of Health, 128(2), 85-94. https://doi.org/10.1177/1466424007087806

Dukes, S., Erica, E., Elizabeth, K., Francesca, S., Marion, M., Lynn, J., ... Sebastian, D. (2016). The Neighborhood Strikes Back: Community Murals by Youth in Boston's Communities of Color, 24(1), 1. https://doi.org/10.1111/ciso.12000.T

Effendy, S. M. (2018). Roles of Art as New Urbanism Potential for New City Landmark: Case of Kampung Pelangi, Semarang, Indonesia. Environment-Behaviour Proceedings Journal. https://doi.org/10.21834/e-bpj.v3i9.1541 
Gilboa, S., Jaffe, E. D., Vianelli, D., Pastore, A., \& Herstein, R. (2015). A summated rating scale for measuring city image. Cities, 44, 50-59. https://doi.org/10.1016/j.cities.2015.01.002

Gschwend, R. (2015). The Development of Public Art and its Future Passive, Active and Interactive Past, Present and Future. Arts, 4(3), 93-100. https://doi.org/10.3390/arts4030093

Hall, T. I. M., \& Robertson, I. (2001). Public Art and Urban Regeneration : advocacy , claims and critical debates, $26(1), 5-26$.

Januchta-Szostak, A. (2010). The Role of Public Visual Art in Urban Space Recognition. Cognitive Maps, (January), 75-100. https://doi.org/10.5772/7120

Lynch, K. (1960a). Ch. 1-3, App A+B. Image of the City. https://doi.org/10.2307/427643

Lynch, K. (1960b). The Image of The City.

Mansour, H. (2011). The lost identity of the city : The case of Damascus, (August), 0-21.

McCunn, L. J., \& Gifford, R. (2017). Spatial navigation and place imageability in sense of place. Cities, 74(June 2017), 208-218. https://doi.org/10.1016/j.cities.2017.12.006

Motoyama, Y., \& Hanyu, K. (2014). Does public art enrich landscapes? The effect of public art on visual properties and affective appraisals of landscapes. Journal of Environmental Psychology, 40, 14-25.

https://doi.org/10.1016/j.jenvp.2014.04.008

Obed Bima Wicandra. (2005). Berkomunikasi Secara Visual Melalui Mural Di Jogjakarta. Nirmana, 7(2), 126-133.

Retrieved from http://puslit2.petra.ac.id/ejournal/index.php/dkv/article/view/16518

Omar, D., Omar, K. A., Othman, S., \& Yusoff, Z. M. (2016). Youth Participation in Urban Neighbourhood Community. Procedia - Social and Behavioral Sciences, 234, 309-316.

https://doi.org/10.1016/j.sbspro.2016.10.247

Omar, S. S., Sakip, S. R. M., \& Akhir, N. M. (2016). Bringing the New to the Old: Urban Regeneration through Public Arts. Procedia - Social and Behavioral Sciences, 234, 515-524.

https://doi.org/10.1016/j.sbspro.2016.10.270

Quinn, B. (2005). Arts Festivals and the Creative City. Urban Studies, 42(5/6), 1-22.

Rautio, N., Filatova, S., Lehtiniemi, H., \& Miettunen, J. (2018). Living environment and its relationship to depressive mood: A systematic review. International Journal of Social Psychiatry, 64(1), 92-103.

https://doi.org/10.1177/00207640177444582

Rendell, J. (2006). Art and Architecture: A Place Between Jane Rendell 1. London: I. B.Tauris \& Co Ltd.

Riza, M., Doratli, N., \& Fasli, M. (2012). City Branding and Identity. Procedia - Social and Behavioral Sciences, 35(December 2011), 293-300. https://doi.org/10.1016/j.sbspro.2012.02.091

Suthasupa, S. (2012). The Portrayal of a City's Image by Young People. Procedia - Social and Behavioral Sciences, 38(December 2010), 284-292. https://doi.org/10.1016/j.sbspro.2012.03.350

Tsevreni, I. (2014). The Empowering Role of Art in a Critical Pedagogy of Place. Children, Youth and Environments, 24(1), 138-157. 
Sigit, E., et.al. / Asian Journal of Behavioural Studies (AjBeS), 4(16) May / Aug 2019 (pp.1-17)

Vanolo, A. (2008). The image of the creative city: Some reflections on urban branding in Turin. Cities, 25(6), 370382. https://doi.org/10.1016/j.cities.2008.08.001

Zebracki, M. (2013). Beyond public artopia: Public art as perceived by its publics. GeoJournal, 78(2), 303-317. https://doi.org/10.1007/s10708-011-9440-8

Zebracki, M., \& Palmer, Joni m. (2018). Introduction to Special Issue: Urban Public Art: Geographies of CoProduction. City \& Society, 30(1), 5-13. https://doi.org/10.1111/ciso.12152 